\title{
DEBT, FIRM SIZE, AND ACCOUNTING QUALITY: EMPIRICAL EVIDENCE FROM TURKEY
}

\author{
BORÇ, İŞLETME BÜYÜKLÜĞÜ VE MUHASEBE KALİTESİ: TÜRKİYE'DE \\ AMPİIIK BİR ÇALIŞMA
}

\author{
İlhan DALCI ${ }^{*}$ \\ Hasan OZYAPICI ${ }^{* *}$
}

\begin{abstract}
This study aims to investigate how firm size moderates the relationship between debt and accounting quality of the non-financial firms listed on Borsa Istanbul (BIST) in Turkey. The financial data are downloaded from Orbis including the years from 2010 to 2018. Ordinary least squares regression has been applied. This study contributes to the literature by investigating how firm size shapes the impact of leverage on accounting quality. The results of this study show that the effect of leverage on accounting quality is changing depending on the firm size. Accordingly, this study concludes that the magnitude and the direction of the effect of leverage on accounting quality become stronger when the firm size gets smaller.
\end{abstract}

Keywords: Accounting Quality, Debt, Firm Size, Interaction Effect, Leverage, Moderation Effect.

JEL Codes: M40, M41

Öz

Bu çalışma Türkiye'de Borsa İstanbul'da (BIST) işlem gören finansal olmayan firmalarda borç ve muhasebe kalitesi arasındaki ilişkide işletme büyüklügünün rolünü tespit etmeyi amaçlamaktadır. 2010-2018 yıllarını kapsayan finansal veriler Orbis'ten indirilmiştir. Analiz için OLS regresyon modeli kullanılmıştır. Bu çalışma kaldıracın muhasebe kalitesine etkisinin işletme büyüklüğüne bağlı olarak değişip değişmediğini araştırması yönüyle literatüre katkı sağlamaktadır. Çalışmanın bulguları kaldıracın muhasebe kalitesi üzerindeki etkisinin işletme büyüklüğüne bağlı olarak değiştiğini

* Eastern Mediterranean University, Department of Business Administration, E-mail:ilhan.dalci@emu.edu.tr

** Eastern Mediterranean University, Department of Business Administration, Email:hasan.ozyapici@emu.edu.tr 
göstermektedir. Bu bağlamda işletme küçüldükçe kaldıracın muhasebe kalitesi üzerine etkisinin de arttı̆̆ı sonucuna ulaşmıştır.

Anahtar Kelimeler: Muhasebe Kalitesi, Borç, İşletme Büyüklüğü, Etkileşim Etkisi, Kaldıraç, Düzenleyicilik Etkisi.

JEL Kodları: M40, M41

\section{INTRODUCTION}

Turkey has been experiencing a rapid growth in it's economy and it has been an attractive place for international investors (Mert, 2013). Turkey is also one of the candidate countries for the European Union (EU) and there have been negotiations regarding the accession of Turkey into EU (Çelik \& Ecer, 2009). Accordingly, the accession efforts to the EU have necessitated the development and use of high-quality accounting standards to satisfy the needs of international investors (Gücenme Gençoğlu \& Ertan, 2012; Bahadır, Demir, \& Öncel, 2016). In this case, it can be asserted that financial reporting quality is an important issue in Turkey.

Parallel to these developments, it has become mandatory for the listed firms in Turkey to use International Financal Reporting Standards (IFRS) starting from 2005 (Elitaş \& Üç, 2009). There is empirical evidence (Varan \& Balsari, 2014; Adıgüzel, 2017) showing that the use of IFRS has increased financial reporting quality, which is measured as earnings quality, of the listed firms in Turkey. Additionally, some of the empirical studies (Türel, 2009; Suadiye, 2012; Karğ1n, 2013; Özcan, 2017) demonstrate that accounting quality is greater in post-IFRS period when compared to pre-IFRS period in Turkey. However, despite the strong empirical evidence showing that IFRS adoption has an important influence on the quality of accounting information in Turkey, Gücenme Gençoğlu and Ertan (2012) assert that using internationally accepted accounting rules like IFRS is not adequate to improve the quality of accounting information and they note that it is necessary to understand the impact of other factors such as firm size, ownership structure, capital structure, and legal system. Nevertheless, there is a limited number of studies (Gücenme Gençoğlu \& Ertan, 2012; Varan \& Balsari, 2014; Karğın, Aktaş, \& Arıcı, 2015; Kaya \& Yazan, 2017) investigating the impact of these factors on accounting quality of the firms in Turkey. In this regard, Varan and Balsari (2014) investigated the impact of IFRS on accounting quality for the listed firms in BIST (Borsa İstanbul) by taking firm characteristics into account. The authors find that the decrease in the level of loss aversion for post-IFRS period is more significant for larger and low-leverage firms. In another study, Karğın et al. (2015) explored the impact of corporate governance on accounting quality using the financial reports of listed and non-listed firms in BIST Corporate Governance Index. The results of this study show that corporate governance improves the accounting quality. On the other hand, Gücenme Gençoğlu and Ertan (2012) discussed the factors influencing accounting quality in Turkey by conducting a literature 
review. Moreover, Kaya and Yazan (2017) investigated the relationship among corporate social responsibility, earnings management and financial performance.

On the other hand, the general empirical evidence regarding the impact of leverage on accounting quality is inconclusive. This means that, while some of the studies (Baiman \& Verrecchia, 1996; Ahmed \& Courtis, 1999) show that leverage increases accounting quality, some of them (Connors \& Gao, 2011) report leverage-accounting quality relationship. This inconclusive evidence about the impact of leverage on accounting quality might be because of some other factors that may shape how leverage influences the accounting quality. Considering both the inconclusive empirical results in the literature regarding the impact of leverage on accounting quality as well as the research gap regarding the quality of accounting information in Turkey, this study aims to investigate how firm size moderates the relationship between debt and accounting quality of the listed firms in Turkey after IFRS adoption period. This study is different from the other empirical studies conducted in Turkey in a sense that it takes the sample of listed firms after IFRS period and investigates how size of a firm affects leverage-accounting quality relationship. In this regard, the current study is expected to contribute to the research gap and provide important implications for the decision makers.

The remainder of the paper is as follows: the second section outlines the hypothesis development. Next, model specification and data collection are stated in the third section. The fourth section, discusses the results. This is followed by the conclusions in the fifth section.

\section{HYPOTHESIS DEVELOPMENT}

Agency theory can be used to explain how debt increases quality of accounting information through disclosure (Abraham \& Cox, 2007). The Agency theory suggests that agency costs arise as a result of a conflict of interest between managers and shareholders and between shareholders and bondholders. Conflicts between managers and shareholders result from the fact that managers hold less than 100 percent of the residual claim. Because of this reason, managers are motivated to use the organization's resources for their benefits (Jensen \& Meckling, 1976). According to the agency theory, this conflict causes shareholders to engage in actions for their benefits at the expense of bondholders and firm value. Especially, when the risk of default is high, managers have greater incentives to act for benefits of shareholders at the expense of bondholders (Myers, 2001). As a result of this, bondholders want to use protective covenants and monitoring devices in order to protect themselves which in turn create agency costs (Jensen \& Meckling, 1976).

There is an empirical support showing that firms with high leverage have high monitoring and agency costs and the possibility of transfer of wealth from creditors to both shareholders and managers is high (Jensen \& Meckling, 1976). Thus, some of the previous 
studies (Bradbury, 1992; Hossain, Perera, \& Rahman, 1995; Baiman \& Verrecchia, 1996; Ahmed \& Courtis, 1999; Ferguson, Lam, \& Lee, 2002; Abraham \& Cox, 2007) find that firms with high leverage disclose more information and report higher quality financial statements to reduce information asymmetry and agency costs, in order to minimize both the possibility of debt covenant violations and the creditors' perceived risk which may finally decrease the cost of capital (Botosan, 1997). Based on the above strong empirical evidence, it can be stated that leverage enhances financial reporting quality. On the contrary, there is empirical evidence which shows that larger firms have lower agency cost of debt and less monitoring costs when compared to the smaller firms (Michaelas, Chittenden, \& Poutziouris, 1999; Deesomsak, Paudyal, \& Pescetto, 2004). This is due to the fact that, large firms have less volatile cash flow and easy access to capital markets (Ahmed Sheikh \& Wang, 2011). Accordingly, from this argument, it can be inferred that the magnitude and/or direction of the impact of debt on accounting quality may vary according to the firm size. In other words, as the size of a firm becomes bigger, the agency cost of debt gets smaller. Hence, as the size of a firm becomes larger, the impact of leverage on accounting quality weakens. This also means that the smaller the firm size is, the greater the impact of debt on accounting quality becomes. These propositions finally yield the following hypothesis:

$\mathrm{H}$ : The impact of debt on accounting quality is moderated by firm size.

\section{DATA AND MODEL SPECIFICATION}

This study includes non-financial firms listed in BIST. The financial data used to find accruals and accounting quality are downloaded from ORBIS including the years from 2010 to 2018. Although 255 companies have been downloaded, 58 companies have been omitted due to missing data. Finally, 197 companies with 1773 observations are used in this study.

In order to measure accounting quality in this study, performance-adjusted discretionary accruals, which is measured in the following equation, is used (Kothari, Leone, \& Wasley, 2005). In the equation presented below "Accruals" represents total accruals as change in non-cash current assets minus the change in current liabilities excluding the current portion of long-term debt, minus depreciation and amortization (Kothari et al., 2005). Profitability is measured with return on assets (Kothari et al., 2005). The residual from the below equation is used to measure discretionary total accruals. The value of the residual is then multiplied by - 1 to come up with the proxy for accounting quality (Song \& Tuoriniemi, 2016).

$$
\begin{aligned}
\text { Accruals }=\alpha+ & \beta_{1} 1 / \text { Total Assets }_{\mathrm{t}-1}+\beta_{2} \Delta \text { Sales } / \text { Total Assets } \text { Tot }_{t} \\
& +\beta_{3} \text { Property Plant Equipment } t_{\mathrm{t}} / \text { Total Assets }_{\mathrm{t}-1}+\beta_{4} \text { Profitability }+\varepsilon_{\mathrm{t}}
\end{aligned}
$$

The accounting quality measured with the residual of the estimation given above, is then regressed on debt, firm size, the interaction effect of debt and firm size, and control variables. 
Previous literature (Francis, Hanna, \& Vincent, 1996; Roychowdhury, 2006; Lang, Raedy, \& Wilson, 2006; Larcker, Richardson, \& Tuna, 2007; Dechow, Weili, \& Schrand, 2010) generally indicate that such factors as firm growth, firm size, debt, market-to-book ratio, cash flow, capital intensity, profitability, and corporate governance influence accounting quality. Based on these previous studies, we use firm growth, cash flow, and turnover as control variables. In this study, debt is measured as the ratio of total liabilities to total assets (Ebaid, 2016); firm size is natural log of total assets (Song \& Tuoriniemi, 2016); growth is measured as growth of sales (Dimitropoulos, Asteriou, \& Siriopoulos, 2012); cash flow is measured as the ratio of cash flow to total assets (Lang et al., 2006); and turnover is the ratio of sales to total assets (Lang et al., 2006). Consequently, the following equation is derived to measure how firm size shapes the influence of debt on accounting quality:

$A C C Q_{i, t}=\alpha_{t}+\beta_{1}$ Growth $_{i, t}+\beta_{2}$ Cash Flow $_{i, t}+\beta_{3}$ Turnover $_{i, t}+\beta_{4}$ Debt $_{i, t}+\beta_{5}$ Size $_{i, t}+\beta_{6}$ Debt $\times$ Size $_{i, t}+\varepsilon_{i t}$

In this study, initially Ordinary least squares (OLS) method is applied. Random-effects and Fixed-effects methods are then conducted in order to make the results more robust. After OLS, Fixed-effects, and Random-effects are applied, the F-test and Hausman test are performed (Baltagi, 1995). The results show that the $\mathrm{F}$ test is significant $(\mathrm{F}=3.07$, Pro$\mathrm{b}>\mathrm{F}=0.000$ ), therefore, the Fixed-effects is found to be preferable to the OLS. The Hausman test (Chi2 $=415.42$, Prob $>$ Chi2 $=0.000)$ shows that the Fixed-effects method is better than the Random-effects. Accordingly, the OLS and Fixed-effects results are presented for the interpretation of the findings in this study.

\section{RESULTS}

Descriptive statistics and correlation analysis are given in Table I. According to Table I, the mean values of accounting quality, cash flow from operating activities, firm growth, asset turnover, leverage, and firm size are $0.29,0.59,1.47,0.94,0.52$, and 11.37 , respectively.

The correlation analyses in Table I show that there is a significant positive relationship between leverage and accounting quality. On the other hand, cash flow from operating activities, asset turnover, and firm size all have significant negative correlation with accounting quality. 
Table 1: Descriptive statistics and correlation analysis

\begin{tabular}{ccccccccc}
\hline & Mean & SD & ACCQ & CFO & GROWTH & TURN & LEV & SIZE \\
ACCQ & 0.29 & 0.15 & 1 & $-.158^{* *}$ & -.010 & $-.152^{* *}$ & $.160^{* *}$ & $-.165^{* *}$ \\
CFO & 0.59 & 0.24 & & 1 & -.003 & $.110^{* *}$ & $.050^{*}$ & $.087^{* *}$ \\
GROWTH & 1.47 & 204.09 & & & 1 & .021 & .019 & .007 \\
TURN & 0.94 & 0.71 & & & & 1 & $.170^{* *}$ & $.374^{* *}$ \\
LEV & 0.52 & 0.53 & & & & & 1 & .009 \\
SIZE & 11.37 & 2.78 & & & & & & 1 \\
\hline
\end{tabular}

$\overline{\text { ACCQ represents the accounting quality, CFO cash flow from operating activities, GROWTH firm growth, TURN the }}$ asset turnover, LEV the leverage, SIZE firm size.

**. Correlation is significant at the 0.01 level

*. Correlation is significant at the 0.05 level

Table 2, on the other hand, portrays the results of OLS related to the impact of leverage on accounting quality and moderating impact of firm size on the influence of leverage on accounting quality.

Table 2: Results of OLS

\begin{tabular}{|c|c|c|c|c|}
\hline \multirow[t]{3}{*}{ Dependent variable: ACCQ } & \multicolumn{2}{|c|}{ Panel I } & \multicolumn{2}{|c|}{ Panel II } \\
\hline & \multicolumn{2}{|c|}{$\begin{array}{c}\text { Impact of leverage on accounting } \\
\text { quality }\end{array}$} & \multicolumn{2}{|c|}{$\begin{array}{l}\text { Moderating impact of firm size on leverage- } \\
\text { accounting quality relationship }\end{array}$} \\
\hline & Coefficient & $\mathrm{t}$-value & Coefficient & $\mathrm{t}$-value \\
\hline GROWTH & -0.00000887 & -0.53 & -0.00000884 & -0.53 \\
\hline TURN & -0.0401141 & $-8.08^{* *}$ & -0.0395178 & $-7.97^{* *}$ \\
\hline $\mathrm{CFO}$ & -0.1081562 & $-7.71^{* *}$ & -0.1165259 & $-8.13^{* *}$ \\
\hline LEV & 0.0884403 & $11.20^{* *}$ & 0.2675492 & $3.60^{* *}$ \\
\hline SIZE & & & 0.0128613 & $3.12^{* *}$ \\
\hline $\mathrm{LEV} \times \mathrm{SIZE}$ & & & -0.0168844 & $-2.43^{* *}$ \\
\hline $\mathrm{F}$ & \multicolumn{2}{|c|}{$42.70^{* *}$} & \multicolumn{2}{|c|}{$36.68^{* *}$} \\
\hline R-squared & \multicolumn{2}{|c|}{0.1218} & \multicolumn{2}{|c|}{0.1242} \\
\hline Mean VIF & \multicolumn{2}{|c|}{1.04} & \multicolumn{2}{|c|}{1.03} \\
\hline
\end{tabular}

ACCQ represents the accounting quality, CFO cash flow from operating activities, GROWTH firm growth, TURN the asset turnover, LEV the leverage, SIZE firm size. R-squared represents percentage change in the dependent variables caused by the independent variables. VIF represents the variance inflation factor. ${ }^{* *}$ significant at 0.01 level.

Panel I of Table II demonstrates the impact of leverage on accounting quality including growth, turnover and cash flow as control variables. As Panel I shows, both capital intensity $(\beta=-0.0401141, \mathrm{p}<0.01)$ and cash flow $(\beta=-0.1081562, \mathrm{p}<0.01)$ influence accounting quality negatively. The leverage, on the other hand, has a statistically significant positive impact $(\beta=0.0884403, p<0.01)$ on accounting quality. This result supports the notion that firms with high leverage disclose more information and report higher quality financial statements to reduce information asymmetry and agency costs (Ahmed \& Courtis, 1999; Ferguson et al., 2002). In Panel II of Table II, the firm size which is the moderator variable and 
the interaction effect of firm size and leverage (firm size $\times$ leverage) are integrated into the analysis. According to the results, firm size has a statistically significant positive impact ( $\beta=0.0128613, p<0.01)$ on accounting quality. This finding confirms the fact that larger firms report better quality accounting information because they have better corporate governance structures and they are under strict scrutiny by investors and creditors (Hossain et al., 1995; Rajpal, 2012). This result also supports the findings of Varan and Balsari (2014). The results further show that the interaction effect of firm size and leverage on accounting quality ( $\beta=-$ $0.0168844, \mathrm{p}<0.01)$ is highly significant, meaning that firm size moderates the leverage-accounting quality relationship.

Table 3 shown below presents the results of Fixed-effects. Similar to the results of OLS results, the leverage has a statistically significant positive impact $(\beta=0.1967731, \mathrm{p}<0.01)$ on accounting quality. Parallel to the OLS results, the interaction effect of leverage and firm size on accounting quality is also statistically significant and it has a negative sign $(\beta=-0.0719327$, $\mathrm{p}<0.01)$. Consequently, the hypothesis of the study is confirmed.

Table 3: Results of fixed-effects method

\begin{tabular}{ccccc}
\hline & \multicolumn{2}{c}{ Panel I } & \multicolumn{2}{c}{ Panel II } \\
\hline Dependent variable: ACCQ & \multicolumn{2}{c}{$\begin{array}{c}\text { Impact of leverage on accounting } \\
\text { quality }\end{array}$} & $\begin{array}{c}\text { Moderating impact of firm size on } \\
\text { leverage-accounting quality relationship }\end{array}$ \\
\hline GROWTH & Coefficient & t-value & Coefficient & t-value \\
TURN & -0.0000117 & -0.70 & -0.00000998 & -0.63 \\
CFO & -0.177156 & $-15.32^{* *}$ & -0.2150092 & $-18.88^{* *}$ \\
LEV & -0.0907249 & $-6.34^{* *}$ & -0.1247863 & $-8.97^{* *}$ \\
SIZE & 0.1967731 & $11.11^{* *}$ & 0.9765541 & $7.81^{* *}$ \\
LEV × SIZE & & & -0.0734277 & $-5.64^{* *}$ \\
F & & -0.0719327 & $-6.12^{* *}$ \\
R-squared & $120.81^{* *}$ & & $115.53^{* *}$ & \\
F-test & 0.27 & & 0.35 & \\
\hline
\end{tabular}

ACCQ represents the accounting quality, CFO cash flow from operating activities, GROWTH firm growth, TURN the asset turnover, LEV the leverage, SIZE firm size. R-squared represents percentage change in the dependent variables caused by the independent variables. ${ }^{* *}$ significant at 0.01 level. 


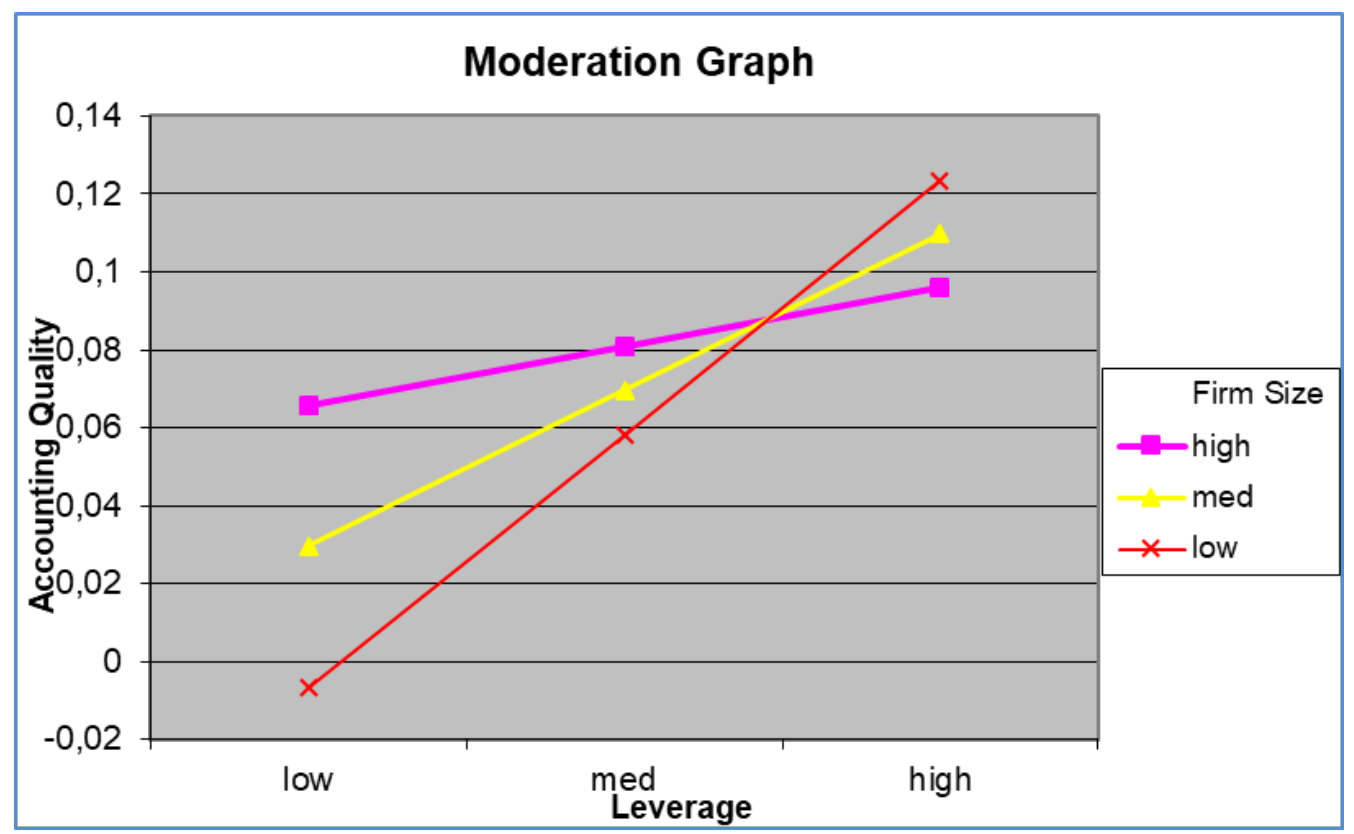

Figure 1. Moderation graph

Based on the regression coefficients reported above, Figure I demonstrates that the impact of leverage on accounting quality changes as the level of firm size varies. Among small firms, as leverage increases, the accounting quality increases. This means that as the level of debt increases, firms report higher quality accounting information. This is also the case for medium-sized firms even though the rate of change in accounting quality is not prominent for small firms when it is compared with larger ones. For the large firms, on the other hand, change in leverage does not cause as sharp increase in accounting quality as it is for small and medium-sized firms. This finding is likely to result from the assumption that since larger firms have lower agency and monitoring costs when compared to the smaller firms, increase in leverage is not expected to increase financial reporting quality as much as it is for the smaller firms. As a consequence, these results indicate that when exploring the impact of leverage on accounting quality, firm size should not be ignored.

\section{CONCLUSION}

In the literature, the impact of leverage on accounting quality is inconclusive. Accordingly, the aim of this study was to investigate how firm size moderates the relationship between leverage and accounting quality of the listed firms in Turkey for post IFRS adoption period. In this respect, the results show that there is a statistically significant positive 
relationship between leverage and accounting quality. When the interaction effect of firm size and leverage is considered, it is found that firm size has a moderating impact on accounting quality. The result of this study implies that the effect of leverage on accounting quality is changing depending on the firm size. Accordingly, the magnitude and the direction of the effect of leverage on accounting quality become stronger when the firm size gets smaller. In this regard, decision makers should evaluate the impact of leverage on accounting quality by taking firm size into consideration.

The current study has several limitations. First, this study takes the sample of firms in a single country. Second, it uses one measure of the accounting quality. In line with these limitations, future research can use the data of other developing countries to test whether the same result can be obtained or not. It is also suggested for further researches that the effect of firm size on the relationship between leverage and accounting quality for firms operating in developing and developed countries can be compared, by taking other measures of the accounting quality into consideration.

\section{REFERENCES}

Abraham, S. \& Cox. P. (2007). Analysing the determinants of narrative risk information in UK FTSE 100 annual reports. The British Accounting Review, 39(3), 227-248.

Adıgüzel, H. (2017). Türkiye'de uluslararası finansal raporlama standartlarına uyumun firmaların kazanç kalitesi üzerine etkisi. Muhasebe ve Denetime Bakış, 51, 103-114.

Ahmed, K. \& Courtis, J. K. (1999). Associations between corporate characteristics and disclosure levels in annual reports: A meta-analysis. The British Accounting Review, 31(1), 35-61.

Ahmed Sheikh, N. \& Wang, Z. (2011). Determinants of capital structure. Managerial Finance, 37(2), 117-133.

Bahadır, O., Demir, V. \& Öncel, A. G. (2016). IFRS implementation in Turkey: benefits and challenges. Accounting and Management Information Systems, 15(1), 5-26.

Baltagi, B. (1995). Econometric Analysis of Panel Data. John Wiley \& Sons, New York, NY.

Baiman, S. \& Verrecchia, R. (1996). The relation among capital markets, financial disclosure, production efficiency, and insider trading. Journal of Accounting Research, 34(1), 1-22.

Botosan, C. A. (1997). Disclosure level and the cost of equity capital. The Accounting Review, 37(2), 323-349.

Bradbury, M. E. (1992). Voluntary disclosure of financial segment data: New Zealand evidence. Accounting and Finance, 32(1), 15-26.

Connors, E. \& Gao, L. S. (2011). Corporate environmental performance, disclosure and leverage: An integrated approach. International Review of Accounting, Banking and Finance, 3(3), $1-26$. 
Çelik, O. \& Ecer, A. (2009). Efficiency in accounting education: Evidence from Turkish universities. Critical Perspectives on Accounting, 20(5), 614-634.

Dechow, P., Weili, G. \& Schrand, C. (2010). Understanding earnings quality: A review of the proxies, their determinants and their consequences. Journal of Accounting and Economics, 50(2), 344-401.

Deesomsak, R., Paudyal, K. \& Pescetto, G. (2004). The determinants of capital structure: Evidence from the Asia Pacific Region. Journal of Multinational Financial Management, 14(4-5), 387-405.

Dimitropoulos, P., Asteriou, D. \& Siriopoulos, C. (2012). Euro adoption and the quality of accounting information. Managerial Auditing Journal, 27(3), 299-328.

Ebaid, I. (2016). International accounting standards and accounting quality in code-law countries. Journal of Financial Regulation and Compliance, 24(1), 41-59.

Elitaş, C. \& Üç, M. (2009). The change on the foundations of Turkish Accounting System and the future perspective, Critical Perspectives on Accounting. 20(5), 674-679.

Ferguson, M. J., Lam, K. C. K. \& Lee, G. M. (2002). Voluntary disclosure by state-owned enterprises listed on the stock exchange of Hong Kong. Journal of International Financial Management \& Accounting, 13(2), 125-152.

Francis, J., Hanna, J. D. \& Vincent L. (1996). Causes and effects of discretionary asset write-offs. Journal of Accounting Research, 34, 117-134.

Gücenme Gençoğlu, Ü. \& Ertan Y. (2012). Muhasebe kalitesini etkileyen faktörler ve Türkiye'deki durum. Muhasebe ve Finansman Dergisi, 53, 1-24.

Hossain, M., Perera, M. H. B. \& Rahman, A. R. (1995). Voluntary disclosure in the annual reports of New Zealand companies. Journal of International Financial Management \& Accounting, 6(1), 69-87.

Jensen, M. C. \& Meckling, W. H. (1976). Theory of the firm: managerial behavior, agency costs and ownership structure. Journal of Financial Economics, 3(4), 305-360.

Karğın, M., Aktaş, R. \& Arıcı, N. D., (2015). Kurumsal yönetimin finansal raporlama kalitesindeki rolü: Borsa İstanbul üzerine karşılaştırmalı bir uygulama. Yönetim ve Ekonomi, 22(2), 501519.

Karğın, S. (2013). The impact of IFRS on the value relevance of accounting information: Evidence from Turkish firms. International Journal of Economics and Finance, 5(4), 71-80.

Kaya, U. \& Yazan, Ö. (2017). Kurumsal sosyal sorumluluk - kazanç yönetimi ve finansal performans ilişkisi. Muhasebe ve Denetime Bakış Dergisi, 51, 15-40.

Kothari, S. P., Leone, A. J. \& Wasley, C. E. (2005). Performance matched discretionary accrual measures. Journal of Accounting and Economics, 39(1), 163-197. 
Lang, M., Raedy, J. S. \& Wilson, W. (2006). Earnings management and cross listing: Are reconciled earnings comparable to US earnings? Journal of Accounting and Economics, 42(1-2), 255 283.

Larcker, D. F., Richardson, S. A. \& Tuna, I. (2007). Corporate governance, accounting outcomes, and organizational performance. The Accounting Review, 82(4), 963-1008.

Mert, İ. (2013). A historical overview of accounting in Turkey. Internal Auditing \& Risk Management, Anul VIII, 3(31), 15-25.

Michaelas, N., Chittenden, F. \& Poutziouris, P. (1999). Financial policy and capital structure choice in U.K. SMEs: Empirical evidence from company panel data. Small Business Economics, 12(2), 113-130.

Myers, S. C. (2001). Capital structure. Journal of Economic Perspectives, 15(2), 81-102.

Özcan, A. (2017). Analysis of value relevance of intangible assets under International Financial Reporting Standards: Evidence from Borsa Istanbul. Mustafa Kemal Üniversitesi Sosyal Bilimler Enstitüsü Dergisi, 14(40), 364-377.

Rajpal, H. (2012). Independent directors and earnings management: Evidence from India. International Journal of Accounting and Financial Management Research, 2(4), 9-24.

Roychowdhury, S. (2006). Earnings management through real activities manipulation. Journal of Accounting and Economics, 42(3), 335-370.

Song, L. \& Tuoriniemi, J. (2016). Accounting quality, governance standards, and syndicated loan contract. Pacific Accounting Review, 28(1), 2-15.

Suadiye, G. (2012). Value relevance of book value \& earnings under the local GAAP and IFRS: Evidence from Turkey. Ege Akademik Bakış, 12(3), 301-310.

Türel, A. (2009). The value relevance of IFRS: The case of Turkey. Economica, 5(1), 119-128.

Varan, S. \& Balsari C. (2014). The adoption of International Financial Reporting Standards (IFRS) and loss avoidance in Turkey. Accounting in Central and Eastern Europe (Research in Accounting in Emerging Economies), 13, 1-25. 